\title{
Companies In Indonesia In The Vortex Of Global Economic Disruption
}

Various efforts to improve the ranking of ease of doing business in Indonesia throughout 2018 are still restrained by exports and imports that have consistently tended to decline since 2015. The World Bank's report on the ease of doing business 2018 places Indonesia on 73rd out of 190 countries. This position was down one position compared to 2017 of 72 nd position. The downgrade of ease of doing business in Indonesia is expected to have no significant impact on investment, both domestically and internationally. The condition of the global economy in 2018 tends to be sluggish and unbalanced, followed by high global financial uncertainty. The United States economy seems to grow strongly, but inflation expectation remains high so the Fed tends to choose to raise the benchmark interest rate.

This research belongs to the qualitative category with the interpretive paradigm, that is, to study the phenomena and the methods used in the research and then interpret findings. The purpose of the interpretative approach is to analyze the reality of global economic uncertainty and the fluctuations of the IDR (Indonesian Rupiah) against the US Dollar and their effect on the lives of companies in Indonesia in order to survive in the market through the power of competitiveness. By using primary data and secondary data, the researchers tried to explore how business people perceive economic disruption and how business people save and shape their own reality so that they are familiar with the economic disruption. The researchers then interpreted the findings based on the perspective used by business people in Indonesia. Data analysis was carried out to obtain accurate and indepth results. This means that the validation of the accuracy of information is done gradually, starting from the procurement of raw data to be processed for the purpose of analysis in order to produce themes and disruption.

From 2014 to 2017, there was an increase in the population of large and medium industries, from 25,094 business entities in 2014 to 30,992 business entities in 2017 , or an increase of 5,898 business entities. Small industry sector also 
experienced an increase, from 3.52 million business entities in 2014 to 4.49 million business entities in 2017, or an increase of 970 thousand small business entities over 4 years. Investment in the manufacturing industry sector in 2014 was IDR 195.74 trillion and rose to IDR 274.09 trillion in 2017. In the first semester of 2018, investment activities in the manufacturing industry sector reached IDR 121.56 trillion (Ministry of Industry of the Republic of Indonesia, 2018). The challenges that arise may come from external or internal factors of the company. This means that business transformation and human resource transformation are important agendas in many companies. Companies that have succeeded in carrying out business and human resource transformation are PT. BNI, Tbk. and PT. Hartono Plantation Indonesia (HPI-Agro). PT. BNI, Tbk. has carried out banking digital transformation by launching several digital products, such as mobile banking, digital loans, mobile remittance, chat banking, and QR Code-based payment applications by preparing millennial talent with different treatment, different learning, and different total reward. HPI-Agro has carried out 9 business transformations in the last 6 years, namely:

(1) changing annual plants into seasonal plants;

(2) changing project development into an established organization;

(3) changing investment mode into operational mode;

(4) changing administration into strategic manager;

(5) changing ad-hoc into planning based;

(6) changing traditional organization into modern one;

(7) changing plantations into agricultural industries;

(8) changing offer into demand management; and

(9) changing followers into innovators.

The scale of transformation is highly dependent on the level of challenges and problems faced by each company. This means that transformation can be done from aspects of strategy, system, management, organization, information technology, human resources, and funding. The transformation process is usually related to innovative ideas and is expected not to violate business ethics and GCG principles. The transformation process must be able to meet the basic principles of GCG, transparency, accountability, responsibility, independence, and fairness. All important guidelines owned, such as the procurement of goods and services, GCG, ethics, internal control, whistleblowing system, and risk management should run well. If all 
steps in the transformation process can be realized, the company will certainly be able to answer the challenges of change and maintain the relevance of its ecosystem.

Competitive advantage has become a necessity for every company in Indonesia in facing economic disruption when the company wants to survive in the domestic and global markets through a massive transformation at all levels and business units operated as well as continuous innovation. Economic disruption has made company leaders face very difficult challenges. The leaders have to strive to be more adaptive in facing the future that is full of volatility, uncertainty, complexity, and ambiguity (VUCA), including being able to bring a positive aura to all employees. Furthermore, the performance target needs to be lowered from the top level to the individual so that each employee can move in the same direction. In addition, they must be able to foster shared value within individual employees and become a role model for all employees. The implementation of GCG in companies proves to be able to increase company value, market value, culture value, the openness of information, effectiveness of the audit system, and risk control. Profit maximization can be obtained if the governance runs well and is always in line with the compliance and suitability of ethics and norms. REFERENCES Dessler, G. 2005. Human Resources Development. Tenth Edition. New Jersey:Prentice Hall. Effendi M.A. 2009. The Power of Good Corporate Governance:Teori dan Implementasi Jakarta: Salemba Empat. Hitt, M.A. Ireland, R.D \& Hoskisson, R.E.2001. "Strategic Management: Concepts: Competitiveness and Globalization", 4th Edition. Stamford USA: Cengage Learning Advances in Social Science, Education and Humanities Research, volume 308177

\section{Reference:}

Ahmad .Z. Tayibnapis University of Surabaya, Surabaya, Indonesia

L. E. Wuryaningsih University of Surabaya, Surabaya, Indonesia

R. Gora University of Satya Negara Indonesia, Jakarta, Indonesia 